\title{
Implications for public health of the religiosity-longevity relation
}

\author{
Marcelo SaAd ${ }^{1 *}$, Roberta de Medeiros ${ }^{2}$ \\ ${ }^{1}$ Universidade de Santo Amaro (Unisa), São Paulo, SP, Brazil \\ ${ }^{2}$ Centro Universitário São Camilo, São Paulo, SP, Brazi
}

Study conducted at Universidade de Santo Amaro (Unisa), São Paulo, SP, Brazil

Article received: 2/6/2017 Accepted for publication: 3/12/2017 *Correspondence: Address: Rua Montesquieu, 371 São Paulo, SP - Brazil Postal code: 04116-190 msaad@uol.com.br

http://dx.doi.org/10.1590/1806-9282.63.10.837

\section{SUMmary}

A growing body of scientific studies has demonstrated a consistently positive association between religious-spiritual (R/S) involvement and beneficial effects on physical health, culminating with increased longevity. This protective effect on the mortality risk is not only statistically significant but also clinically relevant. The mechanisms involved in this association include psycho-neuro-endocrineimmune pathways, greater adherence to healthy behaviors and diverse social factors. Public health strategies could better explore this association. This can be done on an individual (health professionals adopting simple measures) or institutional scale (health institutions joining religious organizations). Some evidence suggests that the benefits of $\mathrm{R} / \mathrm{S}$ to health and longevity would be more present in populations from more religious regions. In this sense, the Americas (Latin and North) are privileged places for the exploration of this association, compared to regions where there is certain indifference about $\mathrm{R} / \mathrm{S}$ practices. Exploring this interface can improve the supply and usage of health care, especially for marginalized populations. To achieve this, health professionals, religious leaders and policy makers need to work together.

Keywords: public health, longevity, psychoneuroimmunology, adaptation, psychological, religion and medicine, spirituality.

\section{INTRODUCTION}

Health is "a state of complete physical, mental and social well-being, and not merely the absence of disease or illness." This definition, adopted by the World Health Organization (WHO) since it was founded, does not include the religious-spiritual dimension. However, the WHO itself has progressively been recognizing the importance of this dimension in the context of health. ${ }^{1}$ Although religiosity and spirituality are distinct constructs, the overlap between them is remarkable and consistent. ${ }^{2}$ Often, therefore, the term religiosity/spirituality $(\mathrm{R} / \mathrm{S})$ is used to refer to transcendent elements of meaning, purpose, and connectivity. ${ }^{3}$

A growing body of scientific studies has demonstrated a consistent positive association between religious involvement and beneficial effects on physical health. ${ }^{4} \mathrm{~A}$ more frequent participation in religious activities is associated with many biological markers indicative of good health in old age, including lower pulse frequencies and overall allostatic load, lower body mass, diastolic blood pressure, C-reactive protein, and Epstein-Barr virus. ${ }^{5}$ Sev- eral clinical and epidemiological studies suggest that religious people are healthier and require less access to health services. In addition to increasing scientific evidence of the association between $\mathrm{R} / \mathrm{S}$ involvement and various health indicators, there is evidence that more frequent participation in religious activities is predictive of a lower mortality risk. ${ }^{6}$

\section{RELIGIOSITY/SPIRITUALITY AND LONGEVITY}

Longitudinal studies published in recent decades have found significant associations between regular attendance at religious services and reduced risk of early mortality among community populations and in some patient populations, such as those undergoing surgery. ${ }^{7}$ A detailed monograph $^{8}$ cited 121 studies examining the relation between R/S and longevity. Most of these studies are prospective and assess baseline $\mathrm{R} / \mathrm{S}$ as a predictor of mortality during follow-up, even after adjustment for other interfering factors. Of 63 methodologically stricter studies, $47(75 \%)$ showed that $\mathrm{R} / \mathrm{S}$ is a significant predictor of greater longevity. The effects are particularly strong if 
attendance at religious services is frequent. On the contrary, infrequent religious participation (never or less than weekly) was associated with significantly higher rates of mortality from circulatory, oncological, digestive and respiratory causes. ${ }^{9}$

Some researchers try to quantify the impact of this relation on the extension of lifespan. Koenig ${ }^{8}$ cited a systematic review and two meta-analyses that confirmed the relation between R/S and longer life span. Survival among frequent participants in religious activities was increased, respectively, by 37,43 and $30 \%$ (mean of effect $37 \%$ ) in these three studies. According to this author, an increase in survival of $37 \%$ is so clinically relevant that it could be compared with the effects of lowering cholesterol, drug use and physical exercise on survival after myocardial infarction. Other authors agree that the practical significance of the association between regular religious participation and better overall health is comparable to commonly recommended practices such as fruit and vegetable consumption, statin therapy, ${ }^{10,11}$ or even to high socioeconomic status. ${ }^{9}$

For many people, $\mathrm{R} / \mathrm{S}$ beliefs and practices are a source of comfort and wisdom to help make sense of what would otherwise seem absurd, pointing out a way to address the basic issues of meaning, value and relationship. They can help people by providing a sense of control, understanding, coping and interpretation of events and experiences. Accordingly, under certain conditions, harmful effects of some religious interpretations on health have been documented for some aspects of religious beliefs and behaviors. ${ }^{6}$ Negative R/S interpretations can lead to internal conflicts over medical issues, and it has been shown that this can predict an increased risk of mortality and worse medical outcomes ${ }^{12}$ even after adjustment for many other confounding variables. $\mathrm{R} / \mathrm{S}$ suffering, like the sustained feeling of having been abandoned by God, tends to increase the chance of early death and refusal of medical treatment for reasons of the same nature. ${ }^{7}$

Further research is needed to better specify subgroups of people with a more relevant association. A systematic review $^{13}$ showed that $\mathrm{R} / \mathrm{S}$ activities (for instance, church attendance) were associated with reduced mortality in studies of healthy populations, but not in studies including individuals afflicted with any disease. This finding differs from other studies, such as that by Park et al. ${ }^{14}$ including patients with congestive heart failure, in which $\mathrm{R} / \mathrm{S}$ reduced the risk of mortality by $20 \%$. There may also be gender difference in the associations between religious participation and longevity. The most relevant effects tend to be observed in women. ${ }^{15,16}$ One author ${ }^{17}$ hypoth- esized that this prevalence exists mainly in certain vulnerable and socioeconomically disadvantaged groups, such as women (discriminated in some social contexts) and people presenting poor health.

In the search for the subgroups that would benefit the most from a positive relation between $\mathrm{R} / \mathrm{S}$ and longevity, one must consider the social context in which research is done. Most of the surveys that yield a statistically significant positive association are based on data from US populations. An article ${ }^{18}$ explored this association in 59 countries and showed that it is found in a relatively small number of places, especially those where religiosity represents a social norm (that is, it is common and socially desirable). According to this article, even within the United States, the association of $\mathrm{R} / \mathrm{S}$ with mortality reduction depends largely on the regional level of religiosity. This may suggest that the benefits of $\mathrm{R} / \mathrm{S}$ for health and longevity would be more present in regions where religious beliefs are rooted. In this sense, the Americas (Latin and North) are privileged places to investigate this association, compared to locations predominantly indifferent to R/S.

\section{Mechanisms of action}

More studies are needed to determine biological factors that mediate the relation between $\mathrm{R} / \mathrm{S}$ and health. Among the many potential pathways, some mechanisms are mentioned below.

\section{Psycho-neuro-endocrine-immune pathways}

Psychological stress interferes with the dynamics of the hypothalamic-pituitary-adrenocortical and sympatheticadrenal-medullary axes. Stress reduction through belief has the potential to modulate the physiological effects derived from these systems. R/S experiments and practices modulate a variety of systems that can influence these descending neural mechanisms. In stressful life events, the expression $\mathrm{R} / \mathrm{S}$ coping refers to the use of beliefs, attitudes or practices to give meaning to suffering and make it more bearable. Meaning seems important to engage and facilitate some psycho-physiological mechanisms, eliciting a response of relaxation. Systems of meaning and feelings of strength help deal with stress and adversity. ${ }^{6} \mathrm{R} / \mathrm{S}$ beliefs allow the individual to reduce stressful reactions by reinterpreting adverse events. This can increase psychological resilience in the face of negative life events, and the individual can react with hope and optimism.

\section{Encouragement of healthy behaviors}

Higher R/S scores are significantly related to the better beneficial behaviors they stimulate, such as exercise, bal- 
anced diet, as well as control of smoking, alcoholism and risky sexual behavior. ${ }^{4}$ Perhaps up to $30 \%$ of the protection that $\mathrm{R} / \mathrm{S}$ confers can be explained by healthier behaviors (especially physical activity) among individuals who regularly attend R/S activities. ${ }^{19}$ Evidence of the importance of adopting a healthy lifestyle for this relation is the finding that mortality rates among people who joined the Seventh-day Adventist Church in childhood are lower than those of members who joined in adulthood. ${ }^{20}$

\section{Social factors}

The health of individuals is often supported by engagement with their religious congregation. Secondary effects of this communion protect the person from social isolation, offering support in times of adversity. They also lead to the strengthening of family and social relationships, giving the individual a sense of belonging and self-esteem. The act of giving social support to church members reduces the effects of the financial problems of the person providing help on their mortality in old age. ${ }^{21}$ Helping others, even more than receiving help, has a stress-reducing effect. ${ }^{15}$ And, as already mentioned in the previous section, the R/S characteristics of the place where one lives could have effects on individual mortality risks. One study even cites the influence of neighbors in a neighborhood of greater R/S activity. ${ }^{22}$

\section{Clinical implications of this knowledge}

The relation between increased R/S activity and longevity are documented, and the medical community must find the practical value or clinical relevance of such information. Knowing such connections, what could healthcare professionals do differently? "Religious participation" is not a form of therapy that could be prescribed, but the public deserves to know how much certain beliefs or behaviors influence their health and well-being, because in light of that information, people could choose to live differently. The patient's $\mathrm{R} / \mathrm{S}$, as a positive disease-coping strategy, can favor the recovery of health. Since the patient's $\mathrm{R} / \mathrm{S}$ may have an impact on her physical and mental health, she should be more valued at the clinical visit.

Medical organizations have emphasized the need to address religious and spiritual issues in patient care as well as in the training of health professionals. These organizations include the American Psychiatric Association, the American Psychological Association, the Accreditation Council for Graduate Medical Association, the American Academy of Family Physicians, the American College of Physicians and the Association of American Medical Colleges. ${ }^{23}$ In a training model for providing $\mathrm{R} / \mathrm{S}$ care in clinical practice, health professionals learn to evaluate this aspect of life, which questions about R/S can affect treatment and when to refer patients for religious guidance. ${ }^{24}$ Even without formal training, some general guidelines ${ }^{25}$ can guide the health professional towards an empathic and open attitude:

- Knowing the religious affiliation of a patient and how sensitive they are regarding their beliefs.

- Ask the patient if he or she has any specific R/S-related needs during the course of treatment.

- Look for the correspondence between the patient's beliefs and the care offered, making small concessions whenever possible.

- Respect the patient's preferences, such as being attended by a professional of the same gender.

- Accept any religious concerns displayed by the patient as an important item in clinical planning.

- Anticipate potential situations in which the patient's belief system can affect clinical decisions.

- Know some basic precepts of the most prevalent religions in your practicing area.

The health professional, however, cannot contradict the guidelines of the healthcare institution where care is provided. Thus, it is fundamental that organizations embrace a philosophy of humanization that encompasses the R/S needs of their patients. In this sense, some attitudes that the institution can adopt include:

- Invest in proactive care for the religious needs of their patients, as an institutional policy.

- Train the health team on how to respect and protect the cultural values and beliefs of the patient.

- Provide R/S-based interventions to support treatment, especially for religious patients.

Inpatient institutions often rely on a chaplain, a clergyman, or lay person specially commissioned by a religious organization to offer pastoral services in institutions such as hospitals. But few outpatient health services can maintain such a structure. Despite this, they can and should value and support the patient's religiosity. One way to do this is by partnering with health programs in faith-based organizations. These programs may focus on primary prevention, general health maintenance, specific approaches (such as cardiovascular health) or support for specific diseases (such as cancer). Health programs in faith-based organizations can significantly improve health outcomes, including lowering cholesterol and blood pressure levels, weight and disease symptoms, and preventative care such as increased use of mammography and self-examination of breast. ${ }^{26}$ 
Faith-based health organizations are relevant to any public health consideration in the world, especially in a low-income population. Although there might be some estrangement between religious communities and health services, their partnership has the potential to be very fruitful, since R/S-based programs are an important source of health provision. There is increasing documentation pointing to a positive effect on treatment outcomes. ${ }^{27}$ Policymakers and religious groups strongly influence the delivery and use of health care, but generally work independently. Exploring the two interfaces can improve the supply and use of health care, especially for marginalized populations. To that end, health professionals, religious leaders and policy makers must work together. ${ }^{27}$

\section{FUTURE DIRECTIONS}

The sum of all the results justifies further research aimed at examining the associations between $\mathrm{R} / \mathrm{S}$ and longevity, and the potential of relevance that such associations may have for clinical practice. To move forward in this direction, some approaches are needed in future studies: ${ }^{28}$

- Prospective observational studies, especially those that examine the interaction between $\mathrm{R} / \mathrm{S}$ and better response to pharmaceutical, biological and surgical treatments.

- Experimental studies to determine whether R/S involvement can influence physiological parameters in response to a laboratory-induced psychological or physical stressor.

- Randomized clinical trials evaluating the effects of an $\mathrm{R} / \mathrm{S}$ intervention on medical or surgical outcomes (e.g., the effect of a chaplain's visit before cardiac surgery on postoperative recovery rate).

\section{Conclusion}

There is growing evidence on the correlation between R/S participation and longevity. In addition to reducing mortality, research data point to a better quality of life and symptom control, ${ }^{29}$ also showing reduced morbidity. The interface between R-S and health can be provocative and controversial; R-S is often seen as a private and subjective area, which lies outside the therapeutic context. But patient beliefs can have a substantial impact on the construction of disease meaning, coping behavior, and treatment preferences. Thus, medical communities need to understand and accept that a patient's R/S is part of their own healing journey. Minimizing the importance of this dimension and imposing obstacles to its use would be the same as failing to implement a fully patient-centered care.

\section{Conflict of interest}

The authors declare no conflict of interest.

\section{Resumo}

Implicações para a saúde pública da relação religiosidade-longevidade

Um corpo crescente de estudos científicos tem demonstrado uma associação positiva consistente entre envolvimento religioso-espiritual (R/E) e efeitos benéficos sobre a saúde física, culminando com aumento da longevidade. Esse efeito protetor sobre o risco de mortalidade é não apenas estatisticamente significante, mas também clinicamente relevante. Os mecanismos envolvidos nessa associação incluem vias psico-neuro-imuno-endocrinológicas, maior adesão a comportamentos saudáveis e diversos fatores sociais. Estratégias de saúde pública poderiam explorar melhor essa associação. Isso pode ser feito em uma escala individual (profissionais de saúde adotando medidas simples) ou institucional (instituições de saúde se associando a organizações religiosas). Algumas evidências sugerem que os benefícios da R/E para a saúde e a longevidade seriam mais presentes em populações de regiões mais religiosas. Nesse sentido, as Américas (Latina e do Norte) são lugares privilegiados para a exploração dessa associação, em comparação com regiões onde predomine certa indiferença sobre práticas R/E. Explorar essa interface pode melhorar a oferta e a utilização de cuidados de saúde, especialmente para as populações marginalizadas. Para isso, é preciso que profissionais de saúde, líderes religiosos e decisores políticos trabalhem em conjunto.

Palavras-chave: saúde pública, longevidade, psiconeuroimunologia, adaptação psicológica, religião e medicina, espiritualidade.

\section{References}

1. World Health Organization. WHOQOL and spirituality, religiousness and personal beliefs (SRPB): report on WHO Consultation. Geneva: WHO/MSA/ MHP; 1998. p. 2-23.

2. Ammerman NT. Spiritual but not religious? Beyond binary choices in the study of religion. J Scientific Study Religion. 2013; 52(2):258-78.

3. Saad M, Medeiros R. Spiritual-religious coping - health services empowering patients' resources. In: Saad M, Medeiros R, editors. Complementary therapies for the contemporary healthcare. Rijeka: InTech Publisher; 2012.

4. Koenig HG. Religion, spirituality, and health: a review and update. Adv Mind Body Med. 2015; 29(3):19-26.

5. Hill TD, Rote SM, Ellison CG, Burdette AM. Religious attendance and biological functioning: a multiple specification approach. J Aging Health 2014; 26(5):766-85 
6. Williams DR, Sternthal MJ. Spirituality, religion and health: evidence and research directions. Med J Aust. 2007; 186(10 Suppl):S47-50

7. Larson DB, Larson SS, Koenig HG. Mortality and religion/spirituality: a brief review of the research. Ann Pharmacother. 2002; 36(6):1090-8.

8. Koenig HG. Religion, spirituality, and health: the research and clinical implications. ISRN Psychiatry. 2012; 2012:278730.

9. Oman D, Kurata JH, Strawbridge WJ, Cohen RD. Religious attendance and cause of death over 31 years. Int J Psychiatry Med. 2002; 32(1):69-89.

10. Lucchetti G, Lucchetti AL, Koenig HG. Impact of spirituality/religiosity on mortality: comparison with other health interventions. Explore (NY). 2011; 7(4):234-8.

11. Hall DE. Religious attendance: more cost-effective than lipitor? J Am Board Fam Med. 2006; 19(2):103-9.

12. Pargament KI, Koenig HG, Tarakeshwar N, Hahn J. Religious struggle as a predictor of mortality among medically ill elderly patients: a 2-year longitudinal study. Arch Inter Med. 2001; 161(15):1881-5.

13. Chida Y, Steptoe A, Powell LH. Religiosity/spirituality and mortality. A systematic quantitative review. Psychother Psychosom. 2009; 78(2):81-90.

14. Park CL, Aldwin CM, Choun S, George L, Suresh DP, Bliss D. Spiritual peace predicts 5-year mortality in congestive heart failure patients. Health Psychol. 2016; 35(3):203-10.

15. la Cour P, Avlund K, Schultz-Larsen K. Religion and survival in a secular region. A twenty year follow-up of 734 Danish adults born in 1914 . Soc Sci Med. 2006; 62(1):157-64.

16. Strawbridge WJ, Shema SJ, Cohen RD, Kaplan GA. Religious attendance increases survival by improving and maintaining good health behaviors, mental health, and social relationships. Ann Behav Med. 2001; 23(1):68-74.

17. Zhang W. Religious participation and mortality risk among the oldest old in China. J Gerontol B Psychol Sci Soc Sci. 2008; 63(5):S293-7.

18. Stavrova O. Religion, self-rated health, and mortality: whether religiosity delays death depends on the cultural context. Social Psychological and Personality Science. 2015; 6(8):911-22.
19. Musick MA, House JS, Williams DR. Attendance at religious services and mortality in a national sample. J Health Soc Behav. 2004; 45(2):198-213.

20. Heuch I, Jacobsen BK, Fraser GE. A cohort study found that earlier and longer Seventh-day Adventist church membership was associated with reduced male mortality. J Clin Epidemiol. 2005; 58(1):83-91.

21. Krause N. Church-based social support and mortality. J Gerontol B Psychol Sci Soc Sci. 2006; 61(3):S140-6.

22. Jaffe DH, Eisenbach Z, Neumark YD, Manor O. Does living in a religiously affiliated neighborhood lower mortality? Ann Epidemiol. 2005; 15(10):804-10.

23. Chattopadhyay S. Religion, spirituality, health and medicine: why should Indian physicians care? J Postgrad Med. 2007; 53(4):262-6.

24. Zollfrank AA, Trevino KM, Cadge W, Balboni MJ, Thiel MM, Fitchett G, et al. Teaching health care providers to provide spiritual care: a pilot study. J Palliat Med. 2015; 18(5):408-14.

25. Anandarajah G, Craigie F Jr, Hatch R, Kliewer S, Marchand L, King D, et al. Toward competency-based curricula in patient-centered spiritual care: recommended competencies for family medicine resident education. Acad Med. 2010; 85(12):1897-904.

26. DeHaven MJ, Hunter IB, Wilder L, Walton JW, Berry J. Health programs in faith-based organizations: are they effective? Am J Public Health. 2004; 94(6):1030-6.

27. Tomkins A, Duff J, Fitzgibbon A, Karam A, Mills EJ, Munnings K, et al. Controversies in faith and health care. Lancet. 2015; 386(10005):1776-85.

28. Lucchese FA, Koenig HG. Religion, spirituality and cardiovascular disease: research, clinical implications, and opportunities in Brazil. Rev Bras Cir Cardiovasc. 2013; 28(1):103-28

29. Petri Jr. RP, Walter JAG, Wright J. Integrative health and healing practices specifically for service members: self-care techniques. Med Acupunct. 2015; 27(5):335-43. 